\author{
KAROLINA JADANOWSKA \\ Uniwersytet im. Mikołaja Kopernika, Wydział Filologiczny, \\ Instytut Języka Polskiego, Zakład Współczesnego Języka Polskiego
}

\title{
Rola słowa w subkulturze hiphopowej
}

Głównym celem artykułu jest przyjrzenie się roli słowa w subkulturze hiphopowej. Oprócz tego, że komunikat werbalny stanowi narzędzie przekazywania wartości oraz ideologii bliskiej członkom tej grupy społecznej, to także stanowi wartość samą w sobie. Taki wniosek możemy postawić po przeanalizowaniu tekstów twórców hiphopowych, którzy traktują słowo zgoła niczym zjawisko sakralne. W drugiej części artykułu postaram się rozpatrzyć subkulturę hiphopową w perspektywie tzw. kultury wtórnej oralności, opisanej głównie przez Waltera Onga [por. Ong 1992].

Socjolodzy oraz językoznawcy niejednokrotnie podkreślają, że muzyka hiphopowa nie istnieje bez słów, które są nośnikiem wartości ludzi tworzących tę subkulturę [Pawlak 2004: 21]. Charakteryzując tę grupę społeczną, bada się teksty piosenek. W nich bowiem zawarta jest ideologia, a sami członkowie subkultury hiphopowej zaznaczają, że taka forma twórczości jest ich autokreacją. Tak więc słowa są dla hiphopowców głównym (aczkolwiek nie jedynym) narzędziem przekazywania idei. Oprócz przekazu werbalnego członkowie tej subkultury wyrażają swoje idee poprzez specyficzny ubiór, gestykulację, zachowania. Te narzędzia stanowią jednak przedmiot zainteresowania socjologów, natomiast artykuł będzie dotyczył przekazu słownego zawartego w tekstach piosenek. To właśnie z wersów utworów dowiadujemy się, że dla członków tej grupy istotne są takie wartości, jak: rodzina, miłość, lojalność, Bóg czy przyjaźń. Szczegółową analizę tego problemu przeprowadzają m.in. Włodzimierz Moch [2008: 273] oraz Joanna Rychla [2005: 49-50]. Starają się oni ustalić hierarchię wartości wyznawanych przez hiphopowców. Jednak z punktu widzenia mojego artykułu istotny jest fakt, że we wspomnianych badaniach nie pojawiło się jako wartość samo stowo, o którym tak często piszą i śpiewają członkowie tej grupy społecznej. Hiphopowcy są bowiem świadomi, że słowa to dla nich nie tylko narzędzia przekazywania idei, ale także wartość sama w sobie. W zebranym przeze mnie materiale językowym odnalazłam takie wersy, jak: 
Słów nie pokonasz, nie zabijesz tych liter.

Słowa to tatuaże. Czarny tusz we krwi $[\ldots]$

Jeśli zdepczesz mi mózg, będą żyły swym życiem

[Hades, Stowa]

Ten fragment utworu Hadesa świadczy, że dla rapera słowa stanowią najpotężniejszą wartość, której nie da się pokonać. Szczególnie daje się zauważyć świadomość twórcy o niemożliwości istnienia świata i cywilizacji bez słów oraz o ich niezniszczalności. Świadczy o tym metafora zawarta w pierwszym wersie cytowanego fragmentu - „Słowa to tatuaże”: słowa często są określane jako ulotne, chwilowe, przestające istnieć z chwilą wymówienia ostatniej głoski; natomiast twórca widzi słowa zupełnie inaczej - jako coś, czego nie możemy się pozbyć, kiedy już wypowiemy jakieś słowo - nie możemy go cofnąć i zostaje ono z nami do końca życia, tak jak tatuaż. Hades skupia się więc na tym, że wypowiedziane słowa mają swoje konsekwencje i skutki, których nie możemy zatrzymać, na tym polegałaby właśnie 'trwałość' czy 'niezniszczalność' słowa.

Z kolei raper o pseudonimie PiH retoryczne pyta „Znasz siłę słów?”, a potem podsumowuje: „Co dzień z życia wnioski nowe i zmagania /A wartość słowa ciągle pozostaje taka sama...". Hiphopowcy zwracają uwagę przede wszystkim na prawdziwość słów, bo tylko takie słowa są cenne. Prawda często ważniejsza jest niż forma, na płycie Hipotonii możemy usłyszeć:

Proste słowa jak prosta mowa jak prosty rap

I zawarte w nim jakże prawdziwe słowa

bądź też

Potok farmazonów cię gamoniu tylko zgorszy

Przez takich jak ty hip-hop zjeżdża na parter

Prawdziwe słowa to osłona przed fałszem

I nie pokona tego stłamszona lansem

Gwiazda rutyny gdyż rap to nie tylko rymy

[Hipotonia, Proste stowa]

Włodzimierz Moch, badacz języka subkultury hiphopowej w Polsce, obok fatycznej, impresywnej i ekspresywnej funkcji językowej w wypowiedziach hiphopowych, wyróżnia także metalingwistyczną. Funkcja ta, kierująca uwagę na sam kod, ujawnia się w zaskakująco licznych tekstach hiphopowych. Językoznawca dochodzi do następujących wniosków: „Raperzy są wrażliwi na kształt leksykalny i stylistyczny swoich wypowiedzi. Wykazują względnie wysoki poziom samoświadomości językowej, nazywając używany przez siebie język slangiem. [...] Funkcja metajęzykowa pełni dużą rolę w utworach autotematycznych, w których ich autorzy wypowiadają się na temat własnej poetyki i kształtu słowa" 
[Moch 2008: 36]. Na potwierdzenie tej tezy można przywołać fragment utworu Pezeta pt. Slang, w którym możemy usłyszeć:

\author{
Pióra to włosy, mówisz styka to mówisz dosyć \\ Hajs to flota, bymbył zapomniał kokosy koka \\ Wiesz marker to flama, żarcie to szama \\ Plota to fama, bilety zawsze sprawsza ci kanar \\ Klama to spluwa, mówisz dzięki mówisz dziękówa [...] \\ Gadam tym slangiem tak jak gadał Big L \\ Dobrze wiesz, że ten kawałek mógł by być skitem ${ }^{1}$
}

[Pezet, Slang]

Ta często ujawniająca się funkcja świadczy o świadomości twórców na temat odmienności ich języka od oficjalnej polszczyzny.

W tekstach hiphopowych często wykorzystuje się metaforykę walki do scharakteryzowania mocy słów, a same słowa określane są jako broń. Raperzy 'walczą słowem', nazywają siebie 'lirycznymi żołnierzami'. Daje się więc zauważyć liczne zwroty i sformułowania oddające tęsknotę za etosem walki. Hiphopowcy określają swoją 'wojnę' jako 'wojnę liryczną', w której bronią są właśnie słowa. To słowami można pokonać przeciwnika, często słownictwo militarne współwystępuje ze sfomułowaniami poetyckimi, np. 'przeszyją cię liryczne kule', 'wojenne barwy to metafory' czy 'liryczna strategia'. W utworze rapera o pseudonimie Prezes dominantą kompozycyjną jest metafora rapowania jako walki na słowa. Twórca w każdym wersie łączy słownictwo militarne i to związane $\mathrm{z}$ rapowaniem, ze słowami i przekazem. Chciałabym w tym miejscu przytoczyć zaledwie część tego obszernego i stylistycznie bogatego utworu:

Wykuta z rymów zbroja jest akurat, leży jak ulał

Błyszcząc w słońcu metafor, toczy się fabuła

Sens słowa niczym diabeł ukrywa się w szczegółach, nie bujam

Słowo jednego z wojowników w kapturach rozkłada na łopatki jak dżuma

$[\ldots]$

Każde słowo żołnierzem w postaci liter alfabetu wędrującym po papierze

Potem w sferze werbalnej stają się niewidzialne

A ich drogę oświetlają stylu latarnie

Słowa głębokie jak kopalnie toczą swą batalię

Za bitwą bitwa, tylko prawdziwe będą w stanie wytrwać

To wojna błyskawiczna, słowa tną scenę niczym brzytwa [...]

Przemawiam z tego miejsca niczym starożytny orator

Z liryką skrzydlatą, stylem precyzyjnym jak naloty NATO

Zawodowiec, nie amator, prawowity władca, nie uzurpator

Nakazuję rosnąć swoim słowom jak kwiatom [...]

Słowa to mój pokarm, przynoszę je ludzkości jak ogień Prometeusz

${ }^{1}$ Pisownia oryginalna, http://www.tekstowo.pl/piosenka,pezet,slang.html [dostęp 30.03.2013]. 
Teraz przyjrzyj się dziełu, znajdź prawdę w tym eseju

W słowach, które galopują niczym ceny w PRL'u

W słowach, które wbijają się w najgłębszą mózgu czeluść

Póki stoję na pokładzie słowa nie zamierzam oddać steru

[Prezes, Stowa, stowa, stowa ]

Fakt, że w tekstach hiphopowych często pojawia się słownictwo militarne zauważył już Włodzimierz Moch, który interpretuje to zjawisko w następujący sposób: „Sprzęgnięcie zadań militarnych z poezją dobrze się kojarzy w świadomości pokolenia, które poznało w szkole narodową mitologię romantyczną. W takim podejściu wyraża się też tęsknota młodych za udziałem w walce, która je ominęła. [...] Etos walki okazuje się bliski hiphopowcom. Ich pokolenie wyraźnie oczekuje, że zostaną mu postawione ważne cele i sygnalizuje gotowość ich podjęcia" [2008: 171-172].

$\mathrm{Z}$ dużym znaczeniem roli słowa w subkulturze hiphopowej wiąże się także kult mistrza słowa, czyli tak zwanego MC. Tworzenie własnego wizerunku jako poety to ulubione zajęcie wielu 'emce'. Mówią, że tworzą ,rap poezję" [Fokus \&Miuosh, Ten rap to poezja] lub „lirykę uliczną” [HempGru, Uliczna liryka], dbają też, by ich słowo miało jak najdoskonalszy kształt. Zależy im nie tylko na przekazie, ale też na ciekawym stylistycznie kształcie wypowiedzi. Świadomość potęgi rymowanego słowa jest bliska wielu raperom. Często dokonują nawet mitologizacji własnych działań, gdyż wierzą w swoją stylistyczną kreatywność oraz w sprawczą moc języka. Świadczą o tym fragmenty tekstu Prezesa, takie jak: „Słowem roznoszę przeciwników”, „Słowa to mój pokarm, przynoszę je ludzkości jak ogień Prometeusz” lub „Słowem drążę korytarze w systemie” [Prezes, Stowa, słowa, słowa]. Z kolei twórca o pseudonimie Borixon nieskromnie twierdzi: „Wszystko, co mogę dać tobie w tej chwili to moje słowa droższe od pieniędzy” [Borixon, Stowa droższe od pieniędzy].

Podsumowując dotychczasowe uwagi, należy stwierdzić, że hiphopowcy dużą rolę przypisują słowu. Słowo w tej subkulturze jest jedną z najwyższych wartości, członkowie są tego świadomi, często tworzą autotematyczne teksty, śpiewają o tym, jak wiele mogą zdziałać słowem. Twórcy tej subkultury zdają się zauważać prymarność tekstu mówionego nad pisanym. W jednej ze swoich piosenek Paluch stwierdza: „Pomyśl nad tym, wszystko to słowa / Podstawową zasadą życia jest rozmowa". Sądzę, że ta społeczność doskonale wpisuje się w kulturę tzw. oralności wtórnej, o której tak wiele pisał Walter Ong.

$\mathrm{Z}$ racji tego, że wszyscy jesteśmy piśmienni, całkiem niedawno zwróciliśmy uwagę na żywą obecność oralności we współczesnym świecie, spowodowaną rozpowszechnieniem mass mediów [Havelock 2006: 133-134]. Moc oralności została przebudzona po długim uśpieniu dzięki elektronicznej technologii. Wcześniej granicą audytorium była siła głosu mówionego. Teraz pojedynczy głos może, przynajmniej teoretycznie, dotrzeć do całej ludzkości [Havelock 2006: 52]. 
Tę nową oralność, czyli oralność wtórną, w tym także subkulturę hiphopową, cechuje uderzające podobieństwo. Po pierwsze mistyka uczestnictwa: słuchanie słowa mówionego czyni bowiem ze słuchaczy wspólnotę. Odbieranie tego samego przekazu, tych samych idei, wzmacnia poczucie tej wspólnoty. Gdy raper przekazuje słuchaczom swoje myśli, członkowie tejże społeczności stają się zintegrowaną grupą, do której należy też sam twórca. Raper jest nieodłączną postacią wspólnoty, do której przemawia. Zespoły hiphopowe występowały przeważnie na małych scenach klubowych i dbały o więź z publicznością. Jak zauważa Mirosław Pęczak „w hip-hopie przeważnie nie ma dystansu między sceną a widownią, co jest zasadą główną, świadczącą o wybitnie demokratycznym, a z drugiej strony quasi-plemiennym charakterze tej muzyki" [Pęczak 2007]. Poza tym, człowiek przedpiśmienny był zorientowany na daną grupę, ponieważ nie jawiła mu się żadna alternatywa. Inaczej jest dzisiaj - człowiek orientuje się na grupę świadomie i programowo [Ong 1992: 182-183]. Członkowie subkultury hiphopowej i jej twórcy świadomie wybrali tę grupę spośród innych.

Badacz zaznaczał, że w dzisiejszych czasach, co prawda, nie istnieją pierwotne kultury oralne, ale liczne kultury i podkultury, nawet te kojarzone z wysoką technologią, zachowują sporo nastawień właściwych oralności pierwotnej [Ong 1992: 32]. Na podstawie tekstów piosenek hiphopowych można również znaleźć cechy wspólne kulturze oralnej oraz analizowanej subkulturze. Należą do nich: zanurzenie w świecie ludzkiego życia, sytuowanie wiedzy w kontekście ludzkich zmagań, zaangażowanie zamiast dystansu obiektywizującego oraz nacisk na konkretne sytuacje zamiast abstrakcji. Teksty hiphopowe, tak jak myśli kultury oralnej, pozostają blisko realnego życia człowieka. Do takich utworów należy m.in. tekst PiHa Każdy chlopaczyna z bloków czy grupy WWO Każdy ponad każ$d y m$. Wystarczy przytoczyć fragment ze wspomnianego utworu PiHa, by dostrzec obecność wymienionych cech kultury oralnej:

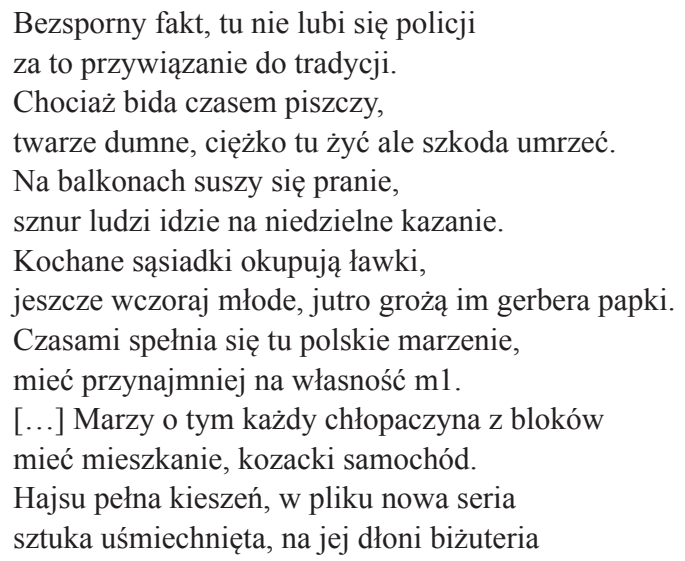


Tematyka tego utworu oscyluje wokół zwykłego życia, poruszane są problemy, takie jak: brak pieniędzy i trudy dnia codziennego. Jednocześnie fragment ten nie zawiera ogólników dotyczących życia, lecz operuje bardzo konkretnymi obrazami, np. suszące się na balkonie pranie czy siedzące na ławkach sąsiadki. Autor sam jest zanurzony w tym świecie, identyfikuje się ze wspólnotą, jest jednym $\mathrm{z}$ uczestników wydarzeń. W tym samym utworze słyszymy bowiem:

\author{
25 lat wstecz z tornistrami idą chłopcy \\ mama mówi nie bierz słodyczy od obcych. \\ $\mathrm{Z}$ workiem na kapcie mijam matematyce \\ do dziś pamiętam zgrzyt jej paznokci o tablice \\ [PiH, Każdy chłopaczyna z bloków]
}

Identyfikując się ze zbiorowością, trudno zachować obiektywizujący dystans. Twórca hiphopowy to twórca zaangażowany, który nie przechodzi obojętnie obok problemów świata realnego, lecz słowem chce go zmieniać lub przynajmniej wiernie opisać. Dlatego też w tekście PiHa został poruszony problem braku pieniędzy, braku perspektyw młodych ludzi, problem stagnacji społeczeństwa, pijaństwa etc. Zaangażowanie twórcy przejawia się również w emocjonalnym podejściu rapera do rzeczywistości. Wyrazem tej emocjonalności są liczne wulgaryzmy pojawiające się w tekstach piosenek, np.

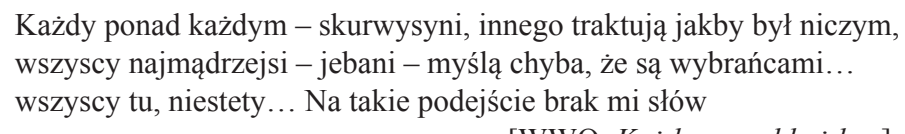

[WWO, Każdy ponad każdym]

Frajdą było przejechanie się taksówką.

Białostocki projekt, suko, nie wakacje w Akapulko

[PiH, Każdy chtopaczyna z bloków]

Mówimy ze sceny, co nas w życiu wkurwia

[Borixon, Stowa droższe od pieniędzy]

Wulgaryzmy nie tylko ujawniają emocjonalny stosunek do rzeczywistości, lecz są pewnym swoistym składnikiem subkultury hiphopowej. Wulgaryzacja tekstów hiphopowych jest osobnym zagadnieniem, któremu należałoby się przyjrzeć w osobnym artykule.

Powracając zaś do społeczeństw pierwotnej oralności, warto zaznaczyć, że słowo było przede wszystkim sposobem działania, a nie odpowiednikiem myśli. Stąd wzięło się przekonanie o sprawczej mocy słowa, które także obecne jest w subkulturze hiphopowej. W ten sposób można tłumaczyć liczne w tekstach hiphopowych porównania słów do broni, którą można zniszczyć przeciwnika, np. „Słowa jak lotnicza eskorda, cele powietrzne i naziemne niszczą w kwadrans” lub „Słowem roznoszę przeciwników, którzy przeciw mnie dobywają miecza” 
[Prezes, Stowa, stowa, stowa].

Pomimo tych podobieństw, Walter Ong zaznaczał, że media elektroniczne i zmiany z nimi związane nie przywróciły pierwotnej oralności i nigdy tego nie zrobią. Dlatego wprowadził właśnie pojęcie wtórnej oralności, która, jak sam zaznacza, ,jest uderzająco podobna, jak i uderzająco niepodobna do oralności pierwotnej" [Ong 1992: 182]. Spoza przesłań głosowych zawsze wyziera przekaz pisemny, rapowany tekst najpierw został starannie przemyślany i zapisany, jednak dopiero po wygłoszeniu czy wyśpiewaniu zyskuje on swoją moc. Havelock w książce pt. Muza uczy się pisać. Rozważania o oralności i piśmienności w kulturze Zachodu nazywa to zjawisko „małżeństwem” pomiędzy zasobami słowa mówionego i pisanego, ponieważ technologia, która na nowo uaktywniła nasz zmysł słuchu, zarazem umocniła zmysł wzroku i władze słowa pisanego, jako tego, które jest widziane i czytane [Havelock 2006: 53].

Celem artykułu było przyjrzenie się roli, jaką odgrywa stowo w subkulturze hiphopowej. Na podstawie przeanalizowanych tekstów można wysunąć wniosek, że kod werbalny to nie tylko narzędzie, za pomocą którego raperzy kreują swoją subkulturę, lecz także - a może przede wszystkim - wartość autoteliczna. Słowo jako wartość sama w sobie bardzo często pojawia się w treści tekstów hiphopowych. Raperzy niejednokrotnie 'oddają kult' słowu, włączając tym samym tę wartość w sferę sacrum. Takie 'oddawanie kultu' słowu polega na opiewaniu jego ogromnej siły oddziaływania, na ciągłym zaznaczaniu sprawczej mocy słowa. Dla twórców hiphopowych rapowane wersy nie są ulotne, a wręcz przeciwnie - są trwałe niczym tatuaż na skórze, raz wypowiedziane mogą zadać ból lub przynieść ukojenie.

$\mathrm{Z}$ tak przedstawionego wniosku wyłania się kolejny, czyli włączenie subkultury hiphopowej w kulturę tzw. oralności wtórnej. Kultury te przejawią wiele wspólnych cech, co starałam się w niniejszym artykule naszkicować. Do cech tych można zaliczyć: nacisk na tworzenie wspólnoty, wyraźnie zaznaczona mistyka uczestnictwa, brak dystansu między członkami zbiorowości, odwoływanie się do konkretnych sytuacji (zamiast abstrakcji), zaangażowanie i emocjonalność oratora, zanurzenie w świat zwykłego życia i w jego problemy. Niniejszy artykuł stanowi jednak zaledwie przyczynek do rozpatrywania subkultury hiphopowej jako nowego wcielenia kultury oralnej. Możemy przypuszczać, że w kolejnych analizowanych tekstach hiphopowych wyżej wymienione cechy również znalazłyby swoje odzwierciedlenie.

\section{Bibliografia}

Anusiewicz J. i Siciński B. (red.) [1994], Języki subkultur, Wydawnictwo Wiedza o Kulturze, Wrocław.

Fliciński P., Wójtowicz S. [2007], Hip-hop słownik, Wydawnictwo Naukowe PWN, Warszawa.

Havelock E. A. [2006], Muza uczy się pisać. Rozważania o oralności i piśmienności w kulturze Za- 
chodu, thum. Majewski P., Wydawnictwo Uniwersytetu Warszawskiego, Warszawa.

Kołodziejczyk E. [2005], Człowiek $i$ świat w języku subkultur, Wydawnictwo Naukowe Uniwersytetu Szczecińskiego, Szczecin.

Kołodziejczyk E. [2007], Swoi i obcy w społecznej przestrzeni subkultur, „Etnolingwistyka”, z. 19.

Kruszewski Z. [2004], Mały słownik subkultur młodzieżowych: na czatach i w oazie, Wydawnictwo Rhetos, Warszawa.

Moch W. [2002], Stownictwo swoiste polskiej subkultury hiphopowej, „Język Polski”, z. 3.

Moch W. [2008], Hip hop - kultura miasta. Leksyka subkultury hiphopowej w Polsce, Wydawnictwo Uczelniane Wyższej Szkoły Gospodarki, Bydgoszcz.

Moch W. [2010], Stowniki hiphopowe jako świadectwa przemian kulturowych, „Linguistica Bidgostiana", z. 7.

Ong W. J. [1992], Oralność i piśmienność. Stowo poddane technologii, tłum. Japola J., Redakcja Wydawnictw Katolickiego Uniwersytetu Lubelskiego, Lublin.

Pawlak R. [2004], Polska kultura hip-hopowa, Wydawnictwo Kagra, Poznań.

Pęczak M. [2011], Hip-hop - wspótczesny wariant kultury oralnej, http://www.rjp.pan.pl/index. php?option $=$ com_content\&view $=$ article $\&$ id $=1366 \&$ Itemid $=50$

Rychla J. [2005], Ucieczka, bunt, twórczość. Subkultura hip-hopowa w poszukiwaniu autentycznego stylu życia, Wydawnictwo Impuls, Kraków.

Szymborska M. [2007], Dominacyjność w tekstach hip-hopowych, „Poznańskie Studia Polonistyczne", z. 14.

\section{Wykaz cytowanych tekstów piosenek}

Borixon, Słowa droższe od pieniędzy, http://tekstyhh.pl/index.php/Borixon/Slowa-drozsze-od-pieniedzy.html

Eldo, Te słowa, http://www.tekstowo.pl/piosenka,eldo,te_slowa.html

Hades, Stowa, http:tekstowo.pl/piosenka,hades,slowa.html

Hipotonia, Proste słowa, http://www.tekstowo.pl/piosenka,hipotonia,proste_slowa.html

Paluch, Stowo ból, http://www.tekstowo.pl/piosenka,paluch,slowo_bol.html

Pezet, Slang, http://www.tekstowo.pl/piosenka,pezet,slang.html

$\mathrm{PiH}$, Każdy chłopaczyna z bloków, http://www.tekstowo.pl/piosenka,pih,kazdy_chlopaczyna_z_ blokow.html

PiH, Waga stowa, http://www.polskirap.net/pih_waga_slowa,65484.html

Prezes, Stowa, stowa, stowa, http://www.tekstowo.pl/piosenka,prezes,slowa_slowa_slowa.html WWO, Każdy ponad każdym, http://www.tekstowo.pl/piosenka,wwo,kazdy_ponad_kazdym.html 